\title{
Development on Iron Ore Pelletization Using Calcined Lime and MgO Combined Flux Replacing Limestone and Bentonite
}

\author{
Jagannath PAL, ${ }^{1 * *}$ Chelladurai ARUNKUMAR, ${ }^{21}$ Yamuzala RAJSHEKHAR, ${ }^{21}$ Gautam DAS, ${ }^{1)}$ \\ Manik Chandra GOSWAMI ${ }^{11}$ and Thirumalachari VENUGOPALAN ${ }^{21}$
}

1) CSIR-National Metallurgical Laboratory, Jamshedpur, Jharkhand, Pin-831007 India. Jharkhand, Pin-831001 India.

2) Tata Steel Ltd, Jamshedpur,

(Received on March 13, 2014; accepted on July 8, 2014)

\begin{abstract}
$\mathrm{CaO}$ and $\mathrm{MgO}$ bearing fluxes are widely used in sinters and pellet to improve their basicity and other properties viz. strength and physico-chemical properties especially, for lowering reduction degradation index of high alumina ore agglomerate. Limestone $\left(\mathrm{CaCO}_{3}\right.$ mineral) is presently used as $\mathrm{CaO}$ input in agglomeration. Endothermic calcination of $\mathrm{CaCO}_{3}$ at elevated temperature is energy consuming and kinetic driven process. Grinding to powder also consumes energy. In contrary, calcined lime is relatively softer and disintegrates on hydration. Calcined and hydrated lime both has very good green bonding property also. Though, calcined/hydrated lime is used in sintering replacing limestone, it is hardly used in pelletization. This is because of facing problems viz. crack formation in pellet, loss in bonding efficiency of bentonite, handling of hydrated lime etc. However, suitable adjustment of flux composition and process parameters can make the calcined lime usable in pelletization as advantage. This study is concentrated on optimization of $\mathrm{MgO}$ (olivine) flux addition and basicity and finally used calcined lime in place of limestone in developing good quality iron ore pellets with combined flux. It is found that calcined lime fluxed pellet without bentonite and limestone shows very good dry compressive strength $(3.5 \mathrm{~kg} / \mathrm{pellet})$ and improved green compressive strength (1.5 kg/pellet), drop numbers (12 Nos ), cold crushing strength (310 kg/pellet) and reduction properties. The complete replacement of limestone and bentonite is found with better pellet properties. The bentonite elimination will help minimizing alumina and silica input in pellet and reduce the cost in pelletization.
\end{abstract}

KEY WORDS: iron ore plletization; combined flux; use of calcined lime; elimination of bentonite; replacement of limestone; pellet properties.

\section{Introduction}

In blast furnace (BF) iron making lime stone is used as source of $\mathrm{CaO}$ to neutralize the all acidic oxides present in iron ore and make fluid slag of suitable basicity. Limestone is the most common source of $\mathrm{CaO}$, abundantly available and it has very good strength properties also which make it suitable for using in blast furnace. At present, the prepared raw materials (agglomerate) viz. sinters and pellets are used in BF in a significant quantity. A certain percentage of lime is used in these prepared raw materials and the limestone charging in blast furnace is partially replaced. The presence of $\mathrm{CaO}$ in the agglomerate also improves its strength and other physical and physic-chemical properties which are found to be more suitable in blast furnace operation.

But this lime input in pellet and sinter is mainly done through direct lime stone addition of desired size. In sintering, calcined lime charging of around $1-2 \%$ has been done by several investigators ${ }^{1,2}$ and it is a useful practice in many steel plants. Most of them have found very good performance in micro balling in secondary drum, sinter quality

* Corresponding author: E-mail: jgpal2003@yahoo.co.in DOI: http://dx.doi.org/10.2355/isijinternational.54.2169 and productivity improvement, better performance of strand, enhancing fines utilization etc.

In pelletization mainly limestone is used as source of $\mathrm{CaO}$. Its calcination is happened at elevated temperature during induration of pellet and provides $\mathrm{CaO}$ to form several calcium containing slag phases (Ca-ferrites or silicates) that improves slag bonding and pellet properties. However, calcination is kinetic driving process and it consumes energy for endothermic reaction. It has hardly any green bonding property. Grinding of lime stone to suitable size also require high energy. In contrary, calcined lime is relatively softer it is a very good bonding material in green condition. ${ }^{3)}$ Cacined lime becomes hydroxide when it gets moisture during mix preparation for agglomerate and degrades in to very fine powder and homogeneously distributes throughout the mix. This distribution of very fine materials over the grain surface in conjunction with water helps improving cohesiveness of particles and form bonding.

If calcined lime/hydroxide lime is used in place of lime stone, its above character may help improving properties of green pellet as well as idurated pellet. Earlier investigators ${ }^{4-11)}$ have studied on the use of hydroxide lime in iron ore pellets and found some encouraging results. De Sauja ${ }^{4)}$ has shown 
the advantages of using hydrated lime in pelletzation and reported to achieve average $367 \mathrm{~kg}$ cold crushing strength (CCS), 18.5\% swelling index and 69\% reducibility index of indurated pellets. Very high green compressive strength (4 $\mathrm{kg} /$ pellet) drop numbers (10.4) and dry compressive strength has been reported by Eisele and Kawatra ${ }^{3)}$ when hydroxide lime is used. However, some investigators have observed severe cracking in green and dry pellets made with hydroxide lime. They have mentioned that the cracks are due to the loss of plasticity on the use of high amount of hydrates lime. ${ }^{5)}$ Holley $^{6}$ has found several advantages of using calcined lime but he has mentioned that expansion of lime during hydration may cause disintegration of green pellets. Therefore, lime should be hydrated properly before making green pellet. If the hydration happens after making pellets, the cracks will be generated even the pellet may be crumbled into fine powder. Cracks in indurated hydrated lime pellets have also been observed by other investigators. ${ }^{7)}$ However, they have not report any reason behind this. Further, the addition of calcium hydroxide results in decreasing the efficiency of bentonite as a binder by replacing of the more efficient sodium ion $\left(\mathrm{Na}^{+}\right)$with calcium ion $\left(\mathrm{Ca}^{+2}\right)$ in the interlayer of bentonite, converting it to the more calcic and less efficient one, leading to deterioration of the pellet properties. ${ }^{8,9)}$

It is envisaged from the reported literature that calcined lime or hydrated lime has advantages in providing good bonding to the green pellet as well as fired pellets, due to some disadvantages, such as cracks formation in green, dry or indurated pellets or deterioration of some other properties this is not widely used by the pellet plants till date. The above problems observed by different investigators are may be due to the unsuitable operating parameters (making technique, induration temperature etc) or improper chemistry of the pellets. For examples: inadequate hydration of calcined lime before pelletization that generates cracks, unsuitable basicity etc. may be mentioned. Further, high alumina hematite pellets like Noamundi ore pellet shows very high $\mathrm{RDI},{ }^{12)}$ which requires $\mathrm{MgO}$ bearing flux addition. Therefore, it is necessary to optimize the pellet chemistry and maintain suitable operation condition to get the advantage of calcined lime. Furthermore, in most of the above studies investigators have used bentonite also with calcined lime. Since, calcined lime decreases the bonding efficiency of bentonite but, there is a good strength property of calcined lime, it may be thought to eliminate bentonite in pellet fully. This elimination may reduce the silica and alumina input in pellets with bentonite which, is a good advantage for using in downstream process of blast furnace iron making and lowering in slag volume.

In order to alleviate the above problems, in current study, suitable pellet chemistry viz. $\mathrm{MgO}$ content, basicity etc has been optimized first with experimental study using olivine as $\mathrm{MgO}$ source and limestone as $\mathrm{CaO}$ source and bentonite as binder. Subsequently, limestone and bentonite has been replaced fully by adding calcined lime or hydrated lime maintaining the other parameters same as optimized. Since the hydrated lime handling becomes difficult in actual process, calcined lime $(\mathrm{CaO})$ has been used here and sufficient water is added in the green mixing drum to make green mix containing $5-7 \%$ free moisture in it. The hydration of calcined lime is possible in the mixing drum and it will disintegrate into very fine powder of $\mathrm{Ca}(\mathrm{OH})_{2}$. Therefore, this study mainly aims at the use of calcined lime in place of limestone eliminating the use of bentonite for development of good quality iron ore pellets.

\section{Experimental}

Hematite iron ore fines of Noamundi, India have been used as raw materials. Olivine has been used as $\mathrm{MgO}$ source in some experiments, limestone or calcined lime has been used as $\mathrm{CaO}$ input to increase the basicity of pellets and coke breeze is used as carbon source. All the raw materials and additives have been received from Tata Steel, India. The size fraction of iron ore fines prepared for pelletization is shown in Table 1. Chemical analysis of iron ore and fluxes including bentonite are shown in Tables $\mathbf{2}$ and 3, respectively. The used coke fines of $-0.149 \mathrm{~mm}$ size, contains $85 \%$ fix C, $13 \%$ ash, $1 \%$ moisture and $1 \%$ VM.

The iron ore fines has been mixed with bentonite, coke powder and fluxes in a rotary cone mixer with addition of moisture for hydration of calcined lime and moistening the mix to $7 \%$ of free moisture content. The mixture is then pelletized with requisite quantity of additional water in a disc pelletizer having $700 \mathrm{~mm}$ disc dia. The pellet size is maintained between $+8 \mathrm{~mm}$ to $-15 \mathrm{~mm}$. The percentages of different materials added for blending with iron ore in different types of pellets made along with their group codes are

Table 2. Chemical analysis of iron ore fines, $w \mathrm{t} \%$.

\begin{tabular}{lllllllll}
\hline \multicolumn{1}{c}{ Materials } & $\mathrm{Fe}_{2} \mathrm{O}_{3}$ & $\mathrm{Fe}_{\text {tot }}$ & $\mathrm{SiO}_{2}$ & $\mathrm{Al}_{2} \mathrm{O}_{3}$ & $\mathrm{CaO}$ & $\mathrm{MgO}$ & $\mathrm{P}$ & $\mathrm{S}$ \\
\hline $\begin{array}{l}\text { Noamundi iron } \\
\text { ore fines }\end{array}$ & 93.05 & 65.28 & 1.4 & 2.5 & 0.11 & 0.028 & 0.08 & 0.081 \\
\hline
\end{tabular}

Table 1. Size fraction of iron ore fines used.

\begin{tabular}{ccccccc}
\hline BIS Mesh size & +72 & $-72+100$ & $-100+150$ & $-150+200$ & $-200+350$ & -350 \\
\hline $\mathrm{wt} \%$ & 6.9 & 7.6 & 8.4 & 6.2 & 8.4 & 62.5 \\
\hline
\end{tabular}

Table 3. Chemical compositions of fluxes and bentonite used, wt $\%$.

\begin{tabular}{lccccccccc}
\hline Flux material & $\mathrm{MgO}$ & $\mathrm{CaO}$ & $\mathrm{SiO}_{2}$ & $\mathrm{Al}_{2} \mathrm{O}_{3}$ & $\mathrm{FeO}$ & $\mathrm{Fe}_{2} \mathrm{O}_{3}$ & $\mathrm{Na}_{2} \mathrm{O}$ & $\mathrm{Mn}$ & LOI \\
\hline Olivine & 48.10 & 0.89 & 40.3 & 0.8 & - & - & & 0.3 & - \\
Limestone & 0.7 & 50.51 & 1.7 & 0.8 & - & - & & - & 42.90 \\
Calcined lime & 0.8 & 95.1 & 0.73 & 1.12 & & & - & & \\
Bentonite & 2.57 & 0.94 & 60.84 & 17.81 & 1.92 & 3.1 & 1.6 & 9.59 \\
\hline
\end{tabular}


Table 4. Blending condition of different types of pellets made.

\begin{tabular}{|c|c|c|c|c|c|c|c|c|c|}
\hline \multicolumn{2}{|c|}{ Pellets code } & \multirow{2}{*}{$\begin{array}{c}\text { Bentonite, } \\
\%\end{array}$} & \multirow{2}{*}{$\begin{array}{l}\text { Desired } \\
\mathrm{MgO} \%\end{array}$} & \multirow{2}{*}{$\begin{array}{c}\text { Olivine } \\
\text { added, \% }\end{array}$} & \multirow{2}{*}{$\begin{array}{c}\text { Desired Basicity, } \\
\mathrm{CaO} / \mathrm{SiO}_{2} \text { ratio }\end{array}$} & \multicolumn{2}{|c|}{ Lime used, \% } & \multicolumn{2}{|c|}{ Carbon } \\
\hline Group & Sub group & & & & & Limestone & Calcined lime & Desired $\% \mathrm{C}$ in mix & Equivalent coke, $\%$ \\
\hline \multirow{4}{*}{$\mathrm{A} 1$} & A1-a & 0.3 & 0 & 0 & 0.25 & 0.61 & 0 & 1.0 & 1.18 \\
\hline & A1-b & 0.3 & 0.4 & 0.75 & 0.25 & 0.75 & 0 & 1.0 & 1.19 \\
\hline & A1-c & 0.3 & 0.6 & 1.16 & 0.25 & 0.83 & 0 & 1.0 & 1.2 \\
\hline & A1-d & 0.3 & 1.0 & 2.08 & 0.25 & 0.99 & 0 & 1.0 & 1.21 \\
\hline \multirow{4}{*}{$\mathrm{A} 2$} & A2-a & 0.3 & 1.0 & 2.06 & 0.10 & 0.23 & 0 & 1.0 & 1.2 \\
\hline & A2-b & 0.3 & 1.0 & 2.08 & 0.25 & 0.99 & 0 & 1.0 & 1.21 \\
\hline & A2-c & 0.3 & 1.0 & 2.12 & 0.65 & 3.02 & 0 & 1.0 & 1.23 \\
\hline & A2-d & 0.3 & 1.0 & 2.13 & 0.80 & 3.8 & 0 & 1.0 & 1.24 \\
\hline $\mathrm{A} 3$ & & 0.3 & 1.0 & 2.08 & 0.25 & 0.95 & 0 & 0 & 0 \\
\hline B1 & & 0 & 1.0 & 2.08 & 0.25 & 0 & 0.45 & 0 & 0 \\
\hline B2 & & 0 & 1.0 & 2.08 & 0.25 & 0 & 0.47 & 1.0 & 1.2 \\
\hline
\end{tabular}

Table 5. Chemical condition of mix for different types of pellets made (dry basis) based on the blend composition, wt $\%$.

\begin{tabular}{cccccccc}
\hline $\begin{array}{c}\text { Pellet } \\
\text { code }\end{array}$ & $\mathrm{CaO}$ & $\mathrm{SiO}_{2}$ & $\mathrm{Al}_{2} \mathrm{O}_{3}$ & $\mathrm{MgO}$ & $\begin{array}{c}\text { Basicity } \\
\left(\mathrm{CaO} / \mathrm{SiO}_{2}\right)\end{array}$ & $\mathrm{C}$ & $\begin{array}{c}\text { Fe-oxide plus } \\
\text { other minor } \\
\text { gangue }\end{array}$ \\
\hline $\mathrm{A} 1-\mathrm{a}$ & 0.41 & 1.64 & 2.55 & 0.04 & 0.25 & 1.0 & Rest \\
$\mathrm{A} 1-\mathrm{b}$ & 0.48 & 1.92 & 2.53 & 0.4 & 0.25 & 1.0 & Rest \\
$\mathrm{A} 1-\mathrm{c}$ & 0.52 & 2.07 & 2.52 & 0.6 & 0.25 & 1.0 & Rest \\
$\mathrm{A} 1-\mathrm{d}$ & 0.6 & 2.41 & 2.51 & 1 & 0.25 & 1.0 & Rest \\
$\mathrm{A} 2-\mathrm{a}$ & 0.242 & 2.42 & 2.52 & 1 & 0.10 & 1.0 & Rest \\
$\mathrm{A} 2-\mathrm{b}$ & 0.6 & 2.41 & 2.51 & 1 & 0.25 & 1.0 & Rest \\
$\mathrm{A} 2-\mathrm{c}$ & 1.56 & 2.4 & 2.47 & 1 & 0.65 & 1.0 & Rest \\
$\mathrm{A} 2-\mathrm{d}$ & 1.91 & 2.39 & 2.46 & 1 & 0.80 & 1.0 & Rest \\
$\mathrm{A} 3$ & 0.59 & 2.36 & 2.49 & 1 & 0.25 & 0 & Rest \\
$\mathrm{B} 1$ & 0.54 & 2.18 & 2.46 & 1 & 0.25 & 0 & Rest \\
$\mathrm{B} 2$ & 0.56 & 2.24 & 2.47 & 1 & 0.25 & 1.0 & Rest \\
\hline
\end{tabular}

shown in Table 4. This is estimated based on desired content of $\mathrm{C}, \mathrm{MgO}$ and basicity. The chemical conditions of different types of pellets made in different groups are shown in the Table 5, which are calculated base on the above blend compositions. While the Gr. Code A1 represents the pellets compositions made with varying $\mathrm{MgO}$ content, A2 represents the pellets compositions made with varying basicity. $\mathrm{B} 1$ and $\mathrm{B} 2$ represent the pellets made with hydroxide lime without $\mathrm{C}$ and with $\mathrm{C}$, respectively.

After preparation, the green pellets have been discharged and subjected to tests viz. green compressive strength (GCS), green drop strength number (GDSN), dry compressive strength (DCS) and moisture content.

GCS has been measured just after making green pellets using Hounsfield material testing machine. The green drop strength number has been conventionally measured by repeatedly dropping an individual green pellet upon a mild steel plate from a conventional height of $450 \mathrm{~mm}$. The green pellets have been dried in an oven at $110^{\circ} \mathrm{C}$ for four hours. The moisture content of pellet has been measured by the weight loss suffered by a representative sample (20-25 g) of the green pellet on heating in an oven at $110^{\circ} \mathrm{C}$ for 4 hours to ensure constant weight. DCS of oven dried pellets has been measured in Hounsfield material testing machine (Model: $\mathrm{H}$ $10 \mathrm{~K}-\mathrm{S}$ ) interfaced with $\mathrm{PC}$ and data acquisition system. All the GCS, GDSN and DCS reported are the average value of minimum 20 Nos of pellets with reproducibility of $\pm 5 \%$.

The pellets have been indurated (in varying capacity of $0.1 \mathrm{~kg}$ to $1.5 \mathrm{~kg}$ per batch) in an electrically heated chamber furnace (Mo- $\mathrm{Si}_{2}$ heating element) of hot zone $400 \times 300 \times$ $300 \mathrm{~mm}$ in varying temperature $\left(1250-1300^{\circ} \mathrm{C}\right)$ and induration time (10-25 $\mathrm{min}$ ) using inconel/mullite crucible.

After cooling of indurated pellets, the cold crushing strength (CCS) has been measured using Hounsfield's materials testing machine (Model: $\mathrm{H} 10 \mathrm{~K}-\mathrm{S}$ ) as per standard: ISO 4700. Apparent porosity (standard IS: 1528, part-VIII-1974) of indurated pellets has been measured in kerosene medium.

Extent of reduction of ore in gaseous reducing atmosphere at elevated temperature, i.e. reducibility index (RI) of pellets in this study has been measured as per standard: JIS: M 8713-2000. Swelling index (SI) i.e. percentage volume expansion after reduction at $900^{\circ} \mathrm{C}$ has been measured as per standard: IS: $8624-1995$. After 3 hrs of reduction in gas mixture of $30 \% \mathrm{CO}$ and $70 \% \mathrm{~N}_{2}$ at $900^{\circ} \mathrm{C}$, volume change of pellet has been measured by mercury displacement method. The reduction degradation index (RDI) of several indurated pellets has been measured as per standard: JIS: M 8720-2001.

In order to study the existence of several phases, XRD analyses of indurated pellets after making powders of it $(-0.149 \mathrm{~mm})$ has been carried out for phase analysis by a Siemens D500 X-ray diffractometer using $\mathrm{Cu}-\mathrm{K}_{\propto}$ radiation. The scanning speed has been maintained at $2 \theta, 1 \% \mathrm{~min}$. The existence of several phases has been identified by JCPDS files.

Selected samples has been observed under the optical microscope (LEICA, DM $2500 \mathrm{M}$ ) and Scanning Electron Microscope, in order to study the distribution of phases and pores.

\section{Results and Discussion}

From the Table 2 it is evident that Noamundi hematite ore 
contains very high alumina and it has adverse ratio of silica to alumina due to which it shows very high RDI in acidic as well as basic pellets. ${ }^{12)}$ To reduce this RDI, MgO containing flux is useful as has been mentioned in Sec 1. Therefore, before assessing the performance of hydroxide lime, optimum requirement of $\mathrm{MgO}$ content and basicity is necessary. Performance of hydroxide lime flux has been examined at the optimum level of $\mathrm{MgO}$ and basicity found from this study.

\subsection{Effect of $\mathrm{MgO}$ in Pellets}

The study has been carried out with varying $\mathrm{MgO}$ (olivine) content of pellet (Gr. Code: A1) with constant carbon content of $1.0 \%$, basicity of 0.25 indurating at $1280^{\circ} \mathrm{C}$ for 10 min. The $\mathrm{CaO}$ and $\mathrm{SiO}_{2}$ content of different pellets mix with varying $\mathrm{MgO}$ is presented in Table 5. With increase in olivine percentage up to $1.16 \%$ strength increases monotonically as shown in Fig. 1. $\mathrm{MgO}$ generally does not increase the strength but since olivine contains a significant percentage of silica, it helps facilitating slag bond and increase the CCS of the pellet.

Figure 2 shows that RDI decreases with increase in olivine content and it comes to the very low level of around $11 \%$ with $2.08 \%$ olivine $(1.0 \% \mathrm{MgO})$. However, pellets without olivine show excessively high RDI that may not be suitable for blast furnace application.

High RDI may be ascribed to the transformation of hexagonal hematite into cubic magnetite at low temperature $\left(500-650^{\circ} \mathrm{C}\right)$. It creates volume expansion of $24 \%$ and

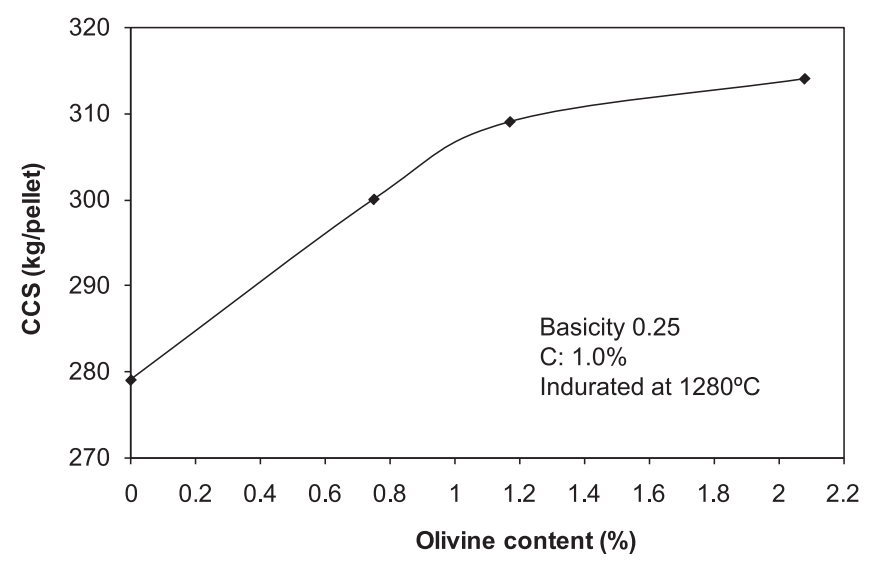

Fig. 1. Effect of olivine $(\mathrm{MgO})$ on $\mathrm{CCS}$ of indurated pellet.

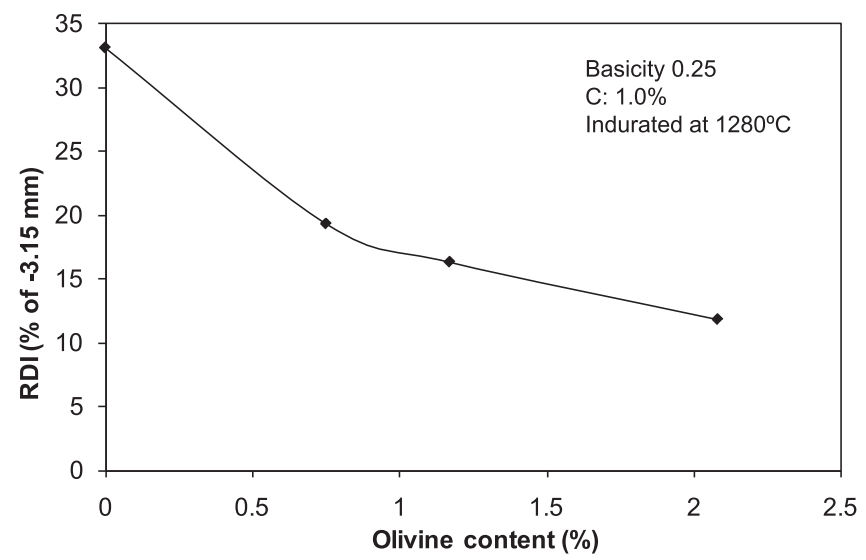

Fig. 2. Effect of olivine (MgO) on RDI of indurated pellets. severe distortion of the lattice. ${ }^{13)}$ Due to this lattice distortion, the internal stresses is developed and acts towards certain planes and causes the cracks to happen in brittle matrix especially in grain boundaries. High $\mathrm{Al}_{2} \mathrm{O}_{3}$ in ore increases the viscosity of the melt phase in pellet due to its high melting temperature. As per $\mathrm{Lu}$ et al. ${ }^{14)}$ increase in $\mathrm{Al}_{2} \mathrm{O}_{3}$ increases the pore area and provides irregular pore shape and thus attributes high RDI due to the presence of alumina as solute in hematite. Pimenta and Seshadri ${ }^{15)}$ also reported that $\mathrm{Al}_{2} \mathrm{O}_{3}$ diffuses in the hematite crystal during induration at high temperature to form solid solution. During reduction at low temperature, hematite with diffused $\mathrm{Al}_{2} \mathrm{O}_{3}$ generates magnetite phase with distorted structure. This phenomenon and volumetric change of the hematite crystal with structural deformation can promote crack initiation and propagation leading to disintegrate the ferrous agglomerates viz. sinter, pellets. Since the present ore is very rich in $\mathrm{Al}_{2} \mathrm{O}_{3}$ resulting high $\mathrm{Al}_{2} \mathrm{O}_{3} / \mathrm{SiO}_{2}(\sim 1.78)$ ratio. This high ratio makes the melt phase viscous, increases brittleness of melt phase on cooling and forms distorted magnetite phase during reduction at low temperature resulting very high RDI of pellet.

Increasing $\mathrm{MgO}$ content leads to more magnetite and less hematite in sinter/pellet ( $\mathrm{Lu}$ et al.), ${ }^{14)}$ because, $\mathrm{MgO}$ in iron oxide crystal forms magnetite spinel during cooling and solidification. It may cause less strain in pellet during reduction. Since the Noamundi ore contains very low $\mathrm{SiO}_{2}(1.4 \%)$ and high alumina, Das et al. ${ }^{16)}$ also suggested to use magnesium silicate flux (olivine, pyroxenite etc) to get excellent benefit in lowering of RDI. The XRD pattern of $2.08 \%$ olivine (i.e. $1 \% \mathrm{MgO}$ ) added indurated pellet is shown in Fig. 3 which contains mainly $\mathrm{Fe}_{2} \mathrm{O}_{3}, \mathrm{CaFeO}_{4}, \mathrm{MgFeAlO}_{4}$ and $\mathrm{CaFeSiO}_{4}$ phases. Though, the separate magnetite phase has not been found in $\mathrm{XRD}$, the $\mathrm{MgFeAlO}_{4}$ spinel phase has been observed. Further, microstructure under optical microscope is shown in Fig. 4 wherein, hematite phase, magnesio ferrite (spinel phase), slag phase and porosity are observed. Therefore, when $\mathrm{MgO}$ content of the pellet has been increased by adding olivine, the RDI has been drastically reduced as shown in Fig. 2. In order to get a good RDI, $1.16-2.1 \%$ olivine addition equivalent to $0.6-1 \% \mathrm{MgO}$ is necessary.

RI of pellet is more or less similar for the different olivine content of pellets as shown in Table 6. Apparent porosity is nearly constant irrespective of $\mathrm{MgO}$ content as shown in

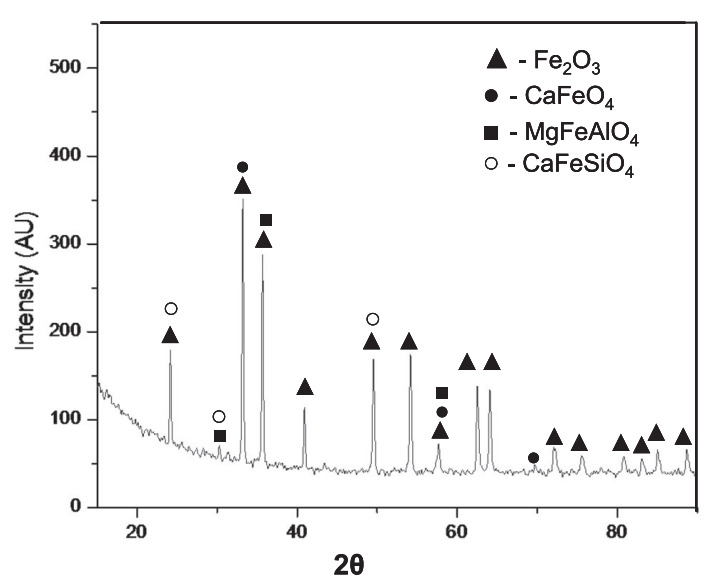

Fig. 3. XRD pattern of $1 \% \mathrm{MgO}$ pellets (B 0.25 ). 


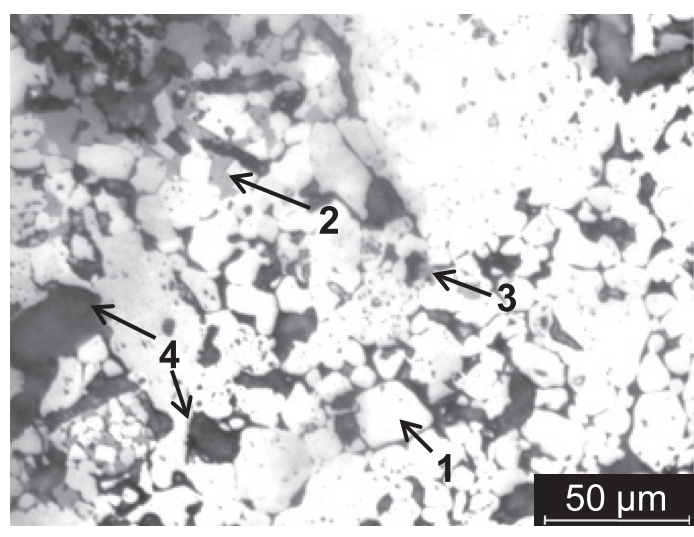

1. Hematite phase, 2. Magnesio ferrite (spinel phase), 3. Slag phase, 4. Pore

Fig. 4. Optical microstructure of olivine $(1 \% \mathrm{MgO})$ containing pellet at $500 \times(1 \% \mathrm{C}$ and $\mathrm{B}=0.25)$.

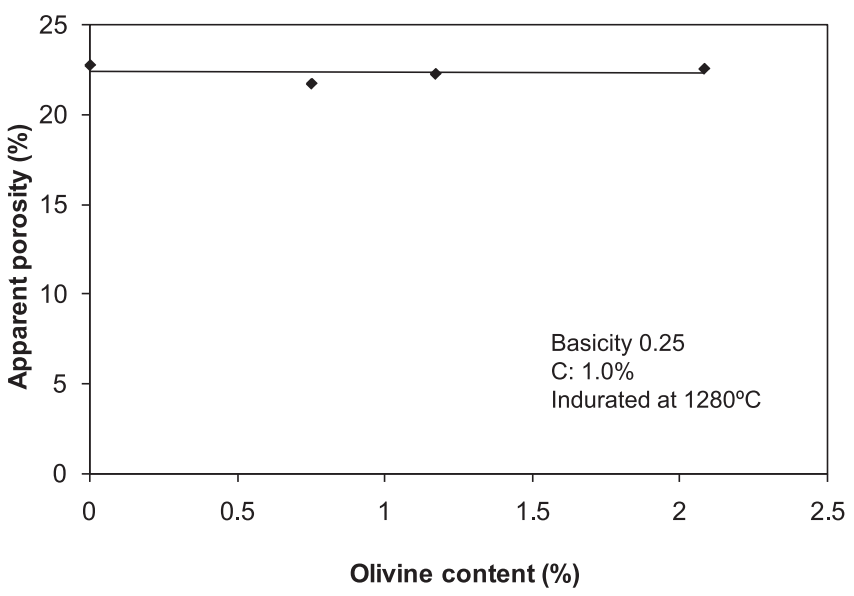

Fig. 5. Effect of olivine (MgO) on apparent porosity of pellets.

Table 6. Other properties of olivine fluxed pellets.

\begin{tabular}{ccccccccc}
\hline $\begin{array}{c}\text { Olivine, } \\
\%\end{array}$ & $\begin{array}{c}\mathrm{MgO}, \\
\%\end{array}$ & $\begin{array}{c}\mathrm{C}, \\
\%\end{array}$ & $\begin{array}{c}\mathrm{CaO}, \\
\%\end{array}$ & $\begin{array}{c}\mathrm{SiO}_{2}, \\
\%\end{array}$ & Basicity & $\begin{array}{c}\text { Indurated } \\
\text { at, }{ }^{\circ} \mathrm{C}\end{array}$ & $\begin{array}{c}\mathrm{RI}, \\
\%\end{array}$ & $\begin{array}{c}\text { Swelling } \\
\text { Index,\% }\end{array}$ \\
\hline 0.75 & 0.4 & 1.0 & 0.48 & 1.92 & 0.25 & 1280 & 76 & 10.3 \\
1.16 & 0.6 & 1.0 & 0.52 & 2.07 & 0.25 & 1280 & 73.8 & 10.5 \\
2.08 & 1.0 & 1.0 & 0.6 & 2.41 & 0.25 & 1280 & 75.3 & 14.7 \\
\hline
\end{tabular}

Fig. 5. This may be the primary reason of getting similar RI for different $\mathrm{MgO}$ containing pellets (Table 6). Swelling index is increasing slightly at $1 \% \mathrm{MgO}$ level but it is also within the acceptable limit. This may be due to the fact that in order to increase $\mathrm{MgO}$ content, olivine (contains around $40 \%$ silica) addition was increased and accordingly, $\mathrm{CaO}$ content of the pellet had to increase up to $0.6 \%$ to keep the basicity at the same level of 0.25 . This increase of lime content of pellet may be the possible reason for slightly increasing swelling for $2.08 \%$ olivine added pellet. The possible reason of increasing swelling with high lime content is explained in the subsequent Sec 3.2. All the above physicochemical properties are quite good in high percentage of $\mathrm{MgO}$. Therefore, $0.6-1 \% \mathrm{MgO}$ addition in form of olivine to reduce RDI does not affect the other properties of pellet and may yield good quality pellet for blast furnace.

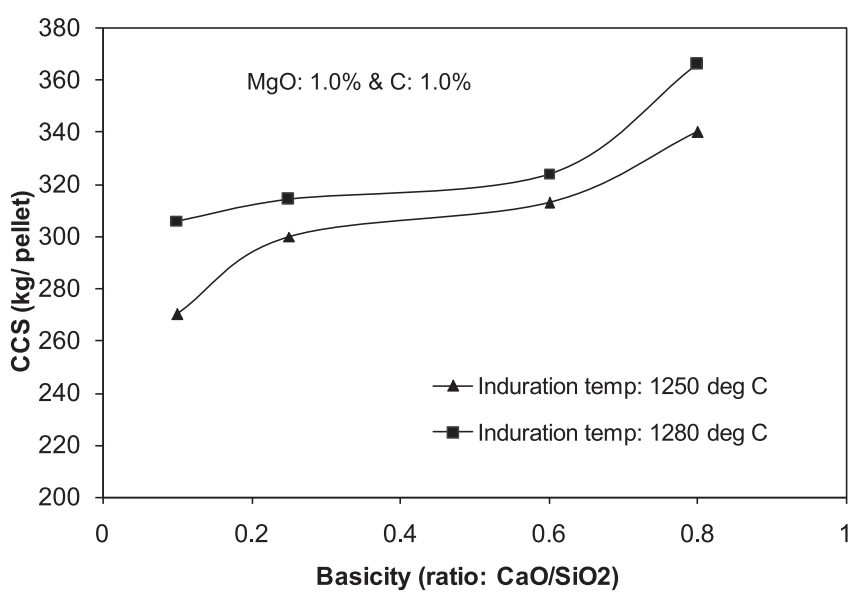

Fig. 6. Effect of basicity on CCS of pellets.

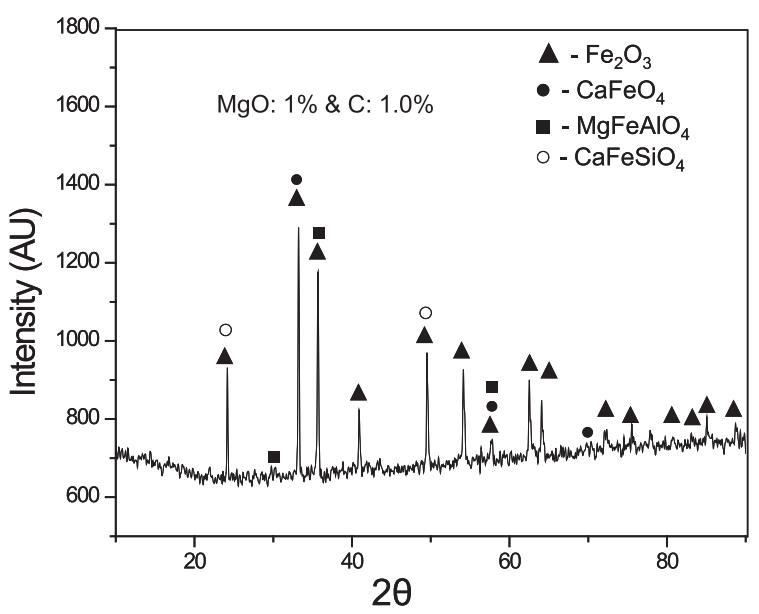

Fig. 7. XRD pattern of high basicity pellet $(B=0.8)$.

\subsection{Effect of Basicity}

In order to study the effect of basicity, the varying limestone added pellets (Gr. Code: A2) with $1 \% \mathrm{C}$ and $1 \% \mathrm{MgO}$ are considered. Basic pellets in all the basicity range shows acceptable green pellets properties (GCS, DCS and GDSN are above $1.2 \mathrm{~kg} /$ pellet, $4.5 \mathrm{~kg} /$ pellet and 12 Nos drops, respectively). The CCS of indurated (at $1280^{\circ} \mathrm{C}$ for $10 \mathrm{~min}$ ) lime stone fluxed pellets increases with increase in basicity of pellets as shown in Fig. 6. This is because of increasing amount of lime may increase the Ca-oxide rich slag bond. Both $\mathrm{CaFeO}_{4}$ and $\mathrm{CaFeSiO}_{4}$ low melting slag phase formation has been found in XRD pattern of $\mathrm{CaO}$ added pellets as shown in Figs. 3 and 7 for 0.25 and 0.8 basicity, respectively. However, the differences in amount of these phases between the pellets of two basicity levels are not clearly distinguishable from XRD patterns. The SEM micro structures of both low and high basicity pellets are shown in Figs. 8 and 9. Light grey phases indicate hematite grains. It also indicates a significant amount of slag phase (dark grey). EDS analysis of slag phases shows $\mathrm{Ca}, \mathrm{Si}, \mathrm{Mg}$ and iron containing phases. It is also depicted from the Figs. 8 and 9 that Ca percentage in slag shows higher (25-30\%) and $\mathrm{Si}$ is lower in high besicity than low basicity pellet. This indicates formation of higher amount of Ca-rich phases like $\mathrm{CaFeO}_{4}$ along with $\mathrm{CaFeSiO}_{4}$ (kirschsteinite glass). This may be the reason to form good slag bonding at high basicity region and increasing CCS. 


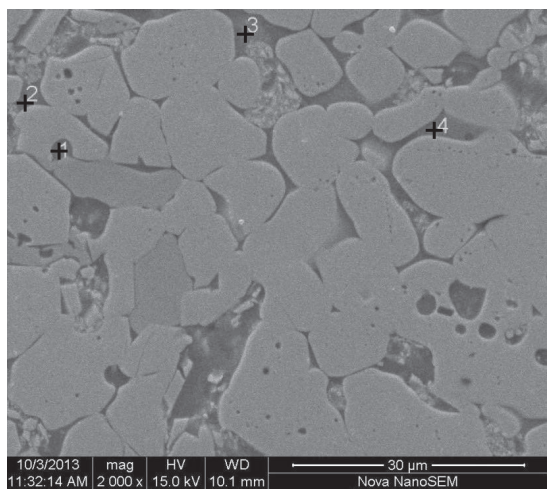

\begin{tabular}{|l|l|l|l|l|}
\hline \multirow{2}{*}{ Elements } & \multicolumn{4}{|c|}{ Slag phases } \\
\cline { 2 - 5 } & Point 1 & Point 2 & Point 3 & Point 4 \\
\hline $\mathrm{O}$ & 21.11 & 21.58 & 19.03 & 20.67 \\
\hline $\mathrm{Mg}$ & 06.49 & 07.54 & 08.14 & 07.22 \\
\hline $\mathrm{Al}$ & 07.99 & 07.23 & 07.25 & 06.54 \\
\hline $\mathrm{Si}$ & 33.58 & 34.36 & 28.09 & 30.26 \\
\hline $\mathrm{Ca}$ & 21.29 & 20.38 & 15.64 & 14.43 \\
\hline $\mathrm{Fe}$ & 09.54 & 08.92 & 21.85 & 20.88 \\
\hline
\end{tabular}

Fig. 8. SEM microstructure of low basicity pellet $(B=0.25)$.

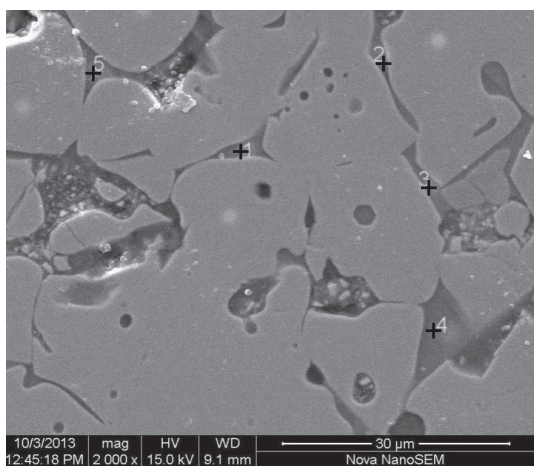

\begin{tabular}{|l|l|l|l|l|l|}
\hline \multirow{2}{*}{ Elements } & \multicolumn{5}{|c|}{ Slag phases } \\
\cline { 2 - 6 } & Point 1 & Point2 & Point 3 & Point 4 & Point5 \\
\hline $\mathrm{O}$ & 17.11 & 17.31 & 15.20 & 16.45 & 16.41 \\
\hline $\mathrm{Mg}$ & 02.90 & 01.33 & 03.75 & 02.48 & 02.09 \\
\hline $\mathrm{Al}$ & 08.52 & 07.24 & 05.05 & 08.61 & 08.60 \\
\hline $\mathrm{Si}$ & 30.65 & 24.90 & 17.79 & 30.16 & 30.29 \\
\hline $\mathrm{Ca}$ & 28.99 & 30.79 & 25.06 & 27.85 & 29.54 \\
\hline $\mathrm{Fe}$ & 11.85 & 18.43 & 33.15 & 14.44 & 13.06 \\
\hline
\end{tabular}

Fig. 9. SEM microstructure of high basicity pellet $(\mathrm{B}=0.8)$.

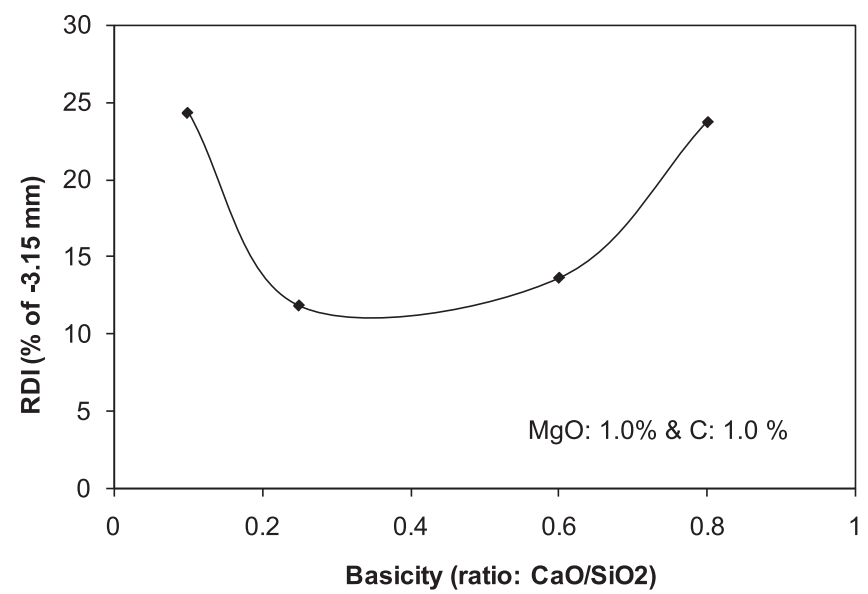

Fig. 10. Effect of basicity on RDI of pellets.

Effect of basicity on RDI of pellets has been presented in Fig. 10. RDI decreases first up to around 0.25 basicity then increases, i.e. minimum are found at 0.25 basicity. While, pellet with low basicity $(0.25-0.5)$ form high silicate glassy phase, the pellet with higher basicity form high calcium glassy phase. The silicate glass phases decrease with increase in pellet basicity. During reduction at lower temperature, the silicate glassy slag in form of plastic state reduce the stress generated due to hematite to magnetite transformation. ${ }^{17}$ ) Thus, the high silicate glass phase containing pellets do not disintegrate on reduction at low temperature. This may be one reason of getting lower RDI at 0.25 basicity level than higher basicity pellets. However, these phases are not separately discernible from XRD.

Further, the optical microstructure of varying basicity is presented in Fig. 11. Figure depicts that higher amount of pore formation in high basisity $(\mathrm{B}=0.8)$ than at lower basicity of pellet. Though the apparent porosity (Table 7) has been found to be nearly same in 0.25 and 0.8 basicity, the microstructure of 0.8 basicity shows large amount of pores. This may be due to the higher amount of closed pores formation during induration in high basicity region. Umadevi et al. ${ }^{18)}$ reported that $\mathrm{CaCO}_{3}$ in limestone particle in pellet decomposed to $\mathrm{CaO}$ and $\mathrm{CO}_{2}$ gas. Then the produced porous and cracked $\mathrm{CaO}$ is dissolved by forming Calcium ferrite, SCA or SFCA phases leaving a pore on that place. This pore may be closed or open. Although in this study, the difference in apparent porosity between limestone added and calcined lime added pellet of similar basicity is not clearly found that may be due to closed pore formation. However, it is evident from the Fig. 11 that that higher lime stone containing pellet has higher porosity than lower limestone containing pellet. This increase in porosity at the high basicity presumably reduce the particle contact area and weaken the pellets to withstand the stress due to expansion during reduction at $550-600^{\circ} \mathrm{C}$. This may be another reason of higher RDI in high basicity pellet. CCS would have been affected by increasing porosity of pellet at high basicity. However, it is not happened in this study that may be due to the increasing amount of slag formation for high amount of lime stone addition. The advantage of high amount of slag phase in high basicity pellet is not so significant in case of RDI because of high calcium glassy phase formation which is less susceptible to withstand stress due to volume expansion than high silicate gassy phase as discussed earlier.

RI and swelling properties are acceptable for low as well as high basicity pellets as shown in Table 7 . The swelling index is slightly higher in 0.8 basicity than 0.25 basicity. One more problem with high basicity is the crack formation 


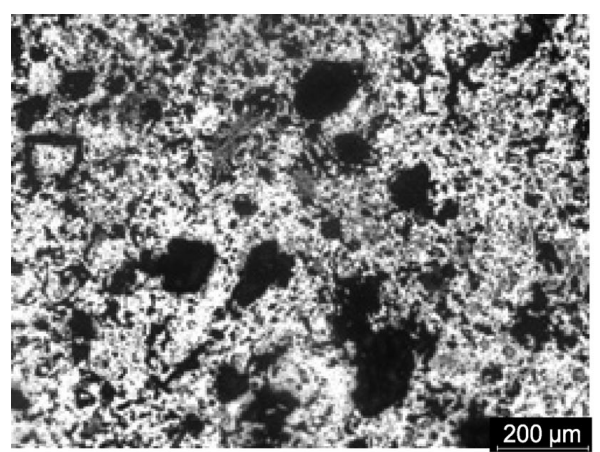

(a) $100 x$

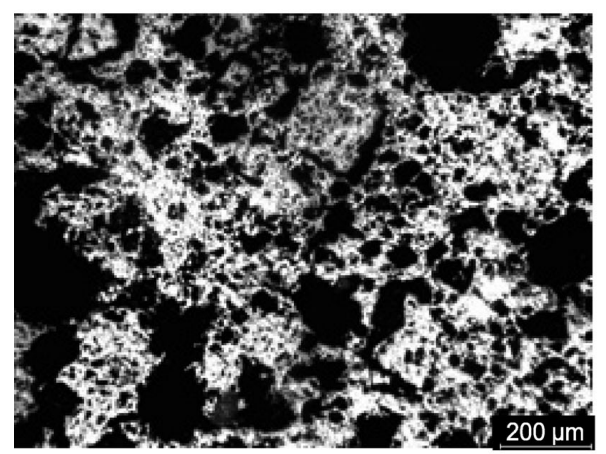

(c) $100 x$

(a) \& (b)basicity : 0.25

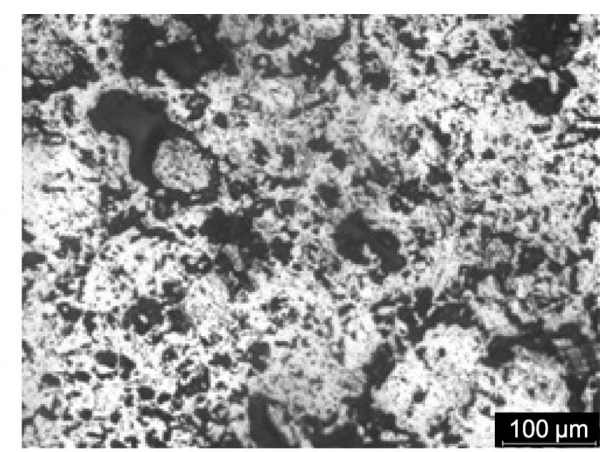

(b) $200 x$

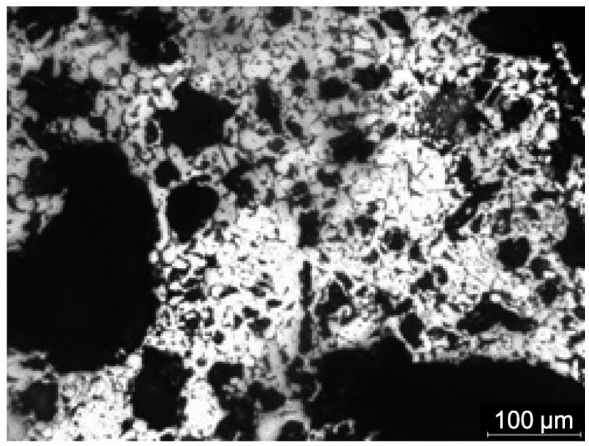

(d) $200 x$

(c) \& (d) basicity $=0.8$

Fig. 11. Optical microstructure of pellets with varying basicity, (C: 1\%, MgO: 1\%).

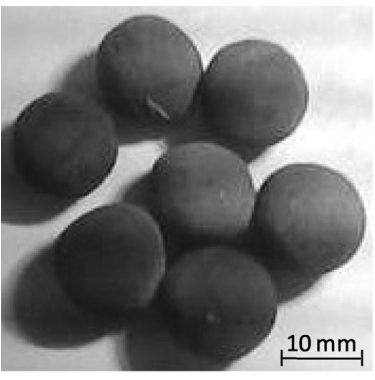

(a) 0.25 Basicity

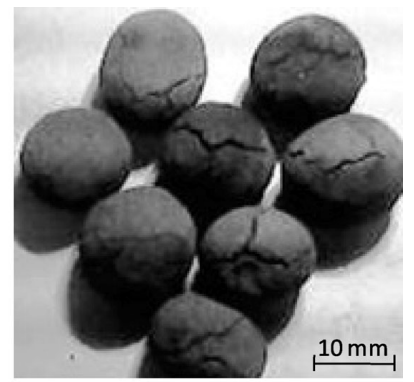

(b) 0.8 Basicity

Fig. 12. Photographs of pellets after swelling on gaseous reduction.

Table 7. RI and swelling index with different basicity.

\begin{tabular}{cccccc}
\hline $\begin{array}{c}\text { Pellet } \\
\text { code }\end{array}$ & Basicity & $\begin{array}{c}\mathrm{CaO}, \\
\%\end{array}$ & $\begin{array}{c}\text { Apparent } \\
\text { Porosity, } \%\end{array}$ & $\begin{array}{c}\mathrm{RI}, \\
\%\end{array}$ & $\begin{array}{c}\text { Swelling } \\
\text { index, \% }\end{array}$ \\
\hline A2-b & 0.25 & 0.6 & 22.6 & 75.3 & 14.7 \\
A2-d & 0.80 & 1.91 & 22.4 & 73.3 & 17.1 \\
\hline
\end{tabular}

in pellets after reduction in RI test as shown in Fig. 12. Umadevi et al. ${ }^{18)}$ has found in high basicity pellets that the conversion of glass phase to the crystallized wllastonite phase happens during reduction at around $800-900^{\circ} \mathrm{C}$ and during conversion, cracks forms over the entire pellet. This may also be the reason of comparatively higher swelling index in 0.8 basicity pellets (i.e high $\mathrm{CaO}$ content). These cracks after reduction may deteriorate the strength at the high temperature zone of blast furnace. Therefore, in order to get all the properties in optimum level, basicity is advis- able to maintain at around 0.25 .

\subsection{Use of Calcined Lime in Pellets}

This study has been carried out with the above optimized $\mathrm{MgO}$ content (1\%) and basicity (0.25) using calcined lime as flux to explore the possibility of using it in place of limestone. The chemical compositions of pellets mix without $\mathrm{C}$ and with $\mathrm{C}$ (Gr. code B1 and B2) is shown in the Table 5 . Calcined lime gets hydrated and form hydroxide during preparation of the moist mix that may have good bonding property. However, as calcined/hydrated lime deteriorate the efficiency of bentonite, ${ }^{8,9)}$ no bentonite has been used in this study for the purpose of assessing the green and dry strength properties of pellet with only lime as binder. The green properties of pellets with limestone plus bentonite ( $\mathrm{Gr}$. Code: A3) and calcined lime (Gr. Code: B1) is shown in Table 8. Calcined lime pellet shows higher green compressive strength and drop strength than the limestone added pellet though no bentonite has been used. This is because of the hydration of calcined lime form $\mathrm{Ca}(\mathrm{OH})_{2}$. Ca-hydroxide has ability to disperse into very small particles in moist medium which is accompanied by an increase in the contact of the combined water and exhibit the strength of the pellet. ${ }^{8)}$ In contrary, limestone added pellets with bentonite show higher DCS than calcined lime pellets without bentonite. This is because bentonite provides very good strength properties to the pellets in dry condition. However, the observed DCS for calcined lime added pellet is $3.5 \mathrm{~kg} /$ pellet that is much higher than desired DCS $(2.2 \mathrm{~kg} / \mathrm{pellet})^{19)}$ in pelletization practice.

Other investigators have used bentonite along with cal- 
Table 8. Green and dry pellets properties of calcined lime and limestone plus bentonite added pellets.

\begin{tabular}{clccccccc}
\hline $\begin{array}{c}\text { Pellet } \\
\text { Code }\end{array}$ & \multicolumn{1}{c}{$\begin{array}{c}\text { Lime flux } \\
\text { added }\end{array}$} & Basicity & $\begin{array}{c}\text { Moisture } \\
\%\end{array}$ & $\begin{array}{c}\mathrm{MgO} \\
\%\end{array}$ & $\begin{array}{c}\text { Bentonite } \\
\%\end{array}$ & $\begin{array}{c}\text { GCS, } \\
\text { Kg/pellet }\end{array}$ & $\begin{array}{c}\text { Green } \\
\text { Drop No }\end{array}$ & $\begin{array}{c}\text { DCS } \\
\text { kg/pellet }\end{array}$ \\
\hline A3 & Limestone: $0.95 \%$ & 0.25 & 8.5 & 1.0 & 0.3 & 1.3 & 9 & 5.5 \\
B1 & Calcined lime: $0.45 \%$ & 0.25 & 8.8 & 1.0 & Nil & 1.5 & 12 & 3.5 \\
\hline
\end{tabular}

Table 9. Compressive strength of pellets with calcined lime and limestone flux after heating.

\begin{tabular}{ccc}
\hline \multicolumn{1}{c}{ Conditions } & $\begin{array}{l}\text { Pellet with limestone } \\
\text { plus bentonite (Pellet } \\
\text { Code: A3), kg/pellet }\end{array}$ & $\begin{array}{l}\text { Pellet with calcined lime } \\
\text { without bentonite (Pellet } \\
\text { Code: B1), kg/pellet }\end{array}$ \\
\hline Dried at $110^{\circ} \mathrm{C}$ for $4 \mathrm{hrs}$ & 5.5 & 3.5 \\
Heated at $800^{\circ} \mathrm{C}$ & 6.5 & 3.0 \\
\hline
\end{tabular}

cined lime as binder. ${ }^{5,8,11)}$ This is possibly because of availing good binding property of bentonite at high temperature. Pellet's dry strength is necessary to withstand the compressive load of bed in dry condition during drying and induration before reaching to the sintering temperature. Therefore, in current study it has been examined whether hydroxide lime can provide good compressive strength after heating at high temperature. Table 9 shows the DCS of pellets in dry condition as well as after heating at $800^{\circ} \mathrm{C}$. In limestone plus bentonite added pellets, DCS increases after heating at $800^{\circ} \mathrm{C}$, but in calcined lime added pellet, DCS deceases after heating at the same temperature. Furthermore, the DCS after heating in case of calcined lime added pellet is almost half of limestone added pellet with bentonite. However, it is much above the acceptable limit.

Further, calcined lime pellets have heated under load at $900^{\circ} \mathrm{C}$ in a chamber furnace. No breaking has been observed as shown in the photograph in Fig. 13. At further higher temperature the diffusion bonding in pellet starts. Therefore, the chance of breaking pellets due to the load of bed in induration strand at high temperature is not expected.

The CCS of indurated pellets both with calcined lime ( $\mathrm{Gr}$. Code: B1) and limestone plus bentonite (Gr. Code: A3) versus induration time at different temperature is shown in Fig. 14. It is envisaged from the figure that at both the temperatures the CCS is highest for 15 min induration. Further, at $1300^{\circ} \mathrm{C}$, it is higher than at $1280^{\circ} \mathrm{C}$ for both the pellets. However, induration at $1280^{\circ} \mathrm{C}$ for 10 minutes also shows good CCS for both pellets such as $260 \mathrm{~kg} /$ pellet for limestone fluxed pellet and $290 \mathrm{~kg} /$ pellet for calcined lime fluxed pellet. Further, Fig. 14 depicts that indurated pellet with calcined lime at both $1280^{\circ} \mathrm{C}$ and $1300^{\circ} \mathrm{C}$ showed higher CCS than limestone plus bentonite added pellets. This higher CCS in calcined lime pellet may be due to the better dispersion ability of $\mathrm{Ca}(\mathrm{OH})_{2}$ in pellet than limestone powder. The endothermic decomposition of $\mathrm{CaCO}_{3}$ in lime stone fluxed pellet at above $900^{\circ} \mathrm{C}$ during induration may be another reason behind this which is discussed in subsequent paragraph.

It is very interesting to observe that when carbon has been used in the pellet mix the strength of both the pellets improved to above $310 \mathrm{~kg} /$ pellet as shown in the Table 10. However, the extent of improvement in CCS of limestone plus bentonite added pellet is much higher than calcined lime pellet. As a result it reaches to the almost same level
Table 10. CCS of limestone plus bentonite and calcined lime added pellets with $1 \% \mathrm{C}$.

\begin{tabular}{|c|c|c|c|c|c|c|c|}
\hline \multirow[t]{2}{*}{$\begin{array}{l}\text { Lime flux } \\
\text { added }\end{array}$} & \multirow[t]{2}{*}{$\begin{array}{l}\text { Pellet } \\
\text { Code }\end{array}$} & \multirow[t]{2}{*}{ Basicity } & \multirow[t]{2}{*}{$\begin{array}{c}\text { Bentonite } \\
\%\end{array}$} & \multirow[t]{2}{*}{$\underset{\%}{\mathrm{MgO}}$} & \multirow[t]{2}{*}{$\begin{array}{l}\text { Induration } \\
\text { time, min }\end{array}$} & \multicolumn{2}{|c|}{$\begin{array}{l}\text { CCS at diff. } \\
\text { Induration } \\
\text { temperature, } \\
\mathrm{kg} / \text { pellet }\end{array}$} \\
\hline & & & & & & $1280^{\circ} \mathrm{C}$ & $300^{\circ} \mathrm{C}$ \\
\hline $\begin{array}{l}\text { Limestone: } \\
0.99 \%\end{array}$ & A2-b & 0.25 & 0.3 & 1.0 & 10 & 310 & 318 \\
\hline $\begin{array}{l}\text { Calcined lime: } \\
0.47 \%\end{array}$ & $\mathrm{~B} 2$ & 0.25 & Nil & 1.0 & 10 & 312 & 315 \\
\hline
\end{tabular}

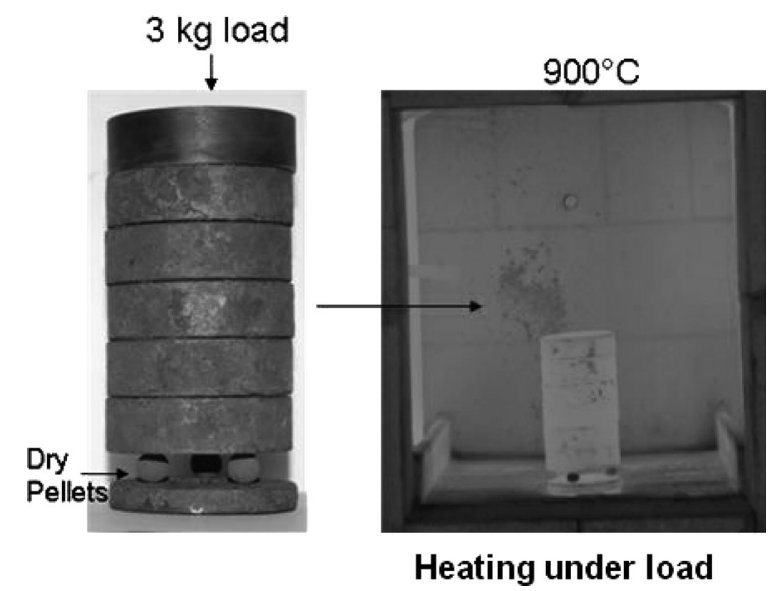

Fig. 13. Photograph of calcined lime fluxed pellets during heating under load.

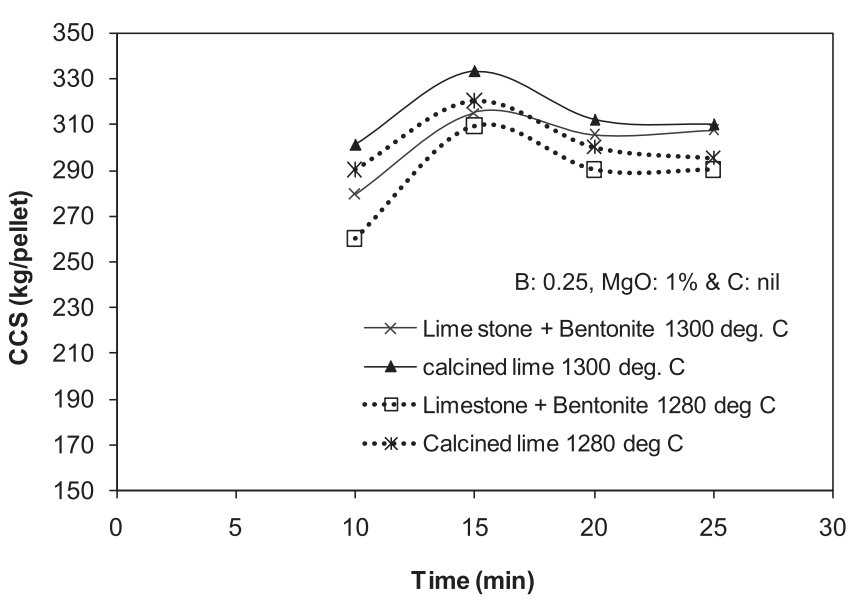

Fig. 14. CCS for calcined lime added and limestone with bentonite added pellets.

and the above differences are not appeared. The possible reason may be the in-situ heat generation due to the oxidation of $\mathrm{C}$ in pellet during induration as per reactions (1) and (2).

$$
\begin{gathered}
\mathrm{C}+1 / 2 \mathrm{O}_{2}=\mathrm{CO}(\mathrm{g}) ; \quad \Delta \mathrm{H}^{0}=-110.5 \mathrm{~kJ} / \mathrm{mol} \\
\mathrm{C}+\mathrm{O}_{2}=\mathrm{CO}_{2}(\mathrm{~g}) ; \quad \Delta \mathrm{H}^{0}=-393.5 \mathrm{~kJ} / \mathrm{mol} \ldots
\end{gathered}
$$


This heat is utilized for endothermic decomposition of $\mathrm{CaCO}_{3}\left(\Delta \mathrm{H}^{0}=179 \mathrm{~kJ} / \mathrm{mol}\right)$ in the limestone added pellet that occurs above $900^{\circ} \mathrm{C}$. Thus, heat evolves from the oxidation of $\mathrm{C}$ meet the internal heat requirement for endothermic reaction helps carbonate pellet for bond formation. In contrary, the decomposition of $\mathrm{Ca}(\mathrm{OH})_{2}$ in calcined lime fluxed pellet is less endothermic $\left(\Delta \mathrm{H}^{\circ}=65.3 \mathrm{~kJ} / \mathrm{mol}\right)$ than $\mathrm{CaCO}_{3}$ decomposition and it occurs at relatively lower temperature $\left(450-500^{\circ} \mathrm{C}\right)$ during drying/preheating of pellet. In calcined lime added pellet also $\mathrm{C}$ oxidize as above but there is no in-situ heat demand for endothermic reaction unlike limestone pellet. Thus, limestone fluxed pellet can utilize the heat of $\mathrm{C}$ oxidation in better way than calcined lime

Table 11. Chemical analysis of limestone added and calcined lime added indurated pellets.

\begin{tabular}{lccccccc}
\hline $\begin{array}{c}\text { Pellet } \\
\text { code }\end{array}$ & $\begin{array}{c}\text { Lime } \\
\text { used }\end{array}$ & $\begin{array}{c}\mathrm{Fe}_{\text {total }}, \\
\%\end{array}$ & $\begin{array}{c}\mathrm{CaO}, \\
\%\end{array}$ & $\mathrm{SiO}_{2}, \%$ & $\begin{array}{c}\mathrm{Al}_{2} \mathrm{O}_{3}, \\
\%\end{array}$ & $\begin{array}{c}\mathrm{MgO}, \\
\%\end{array}$ & Basicity \\
\hline A2-b & Limestone & 65.1 & 0.64 & 2.59 & 2.57 & 1.04 & 0.247 \\
$\mathrm{~B} 2$ & Calcined line & 65.5 & 0.61 & 2.41 & 2.51 & 1.02 & 0.253 \\
\hline
\end{tabular}

fluxed pellet and shows similar strength.

The chemical composition of both calcined lime added pellet and limestone added pellet after induration at $1280^{\circ} \mathrm{C}$ is shown in Table 11. The gangue content such as silica and alumina in limestone added pellet shows slightly higher than calcined lime added pellet. This is mainly due to the use of bentonite in limestone added pellet.

For using in blast furnace, the minimum CCS requirement is $250 \mathrm{~kg} /$ pellet. The other properties viz. RI, RDI and SI of calcined lime added pellets with $1 \% \mathrm{C}$ are $74.7 \%, 12.1 \%$ and $14.9 \%$, respectively as shown in Table 12 . The optimum requirement in blast furnace operation for RI is above $70 \%$ and RDI and SI are below $25 \%$ and $20 \%$, respectively. Thus, the calcined lime added pellet looks perfectly suitable for blast furnace and also comparable with good quality limestone added pellet of similar basicity and $\mathrm{MgO}$ level. The XRD pattern of both calcined lime and limestone added pellets are shown in Figs. 15(a) and 15(b). The peaks with almost same phases $\left(\mathrm{Fe}_{2} \mathrm{O}_{3}, \mathrm{CaFeO}_{4}, \mathrm{MgFeAlO}_{4}, \mathrm{CaFeSiO}_{4}\right)$ are found. Optical micrographs (Fig. 16) shows hematite, magnetite, slag and pores in both the pellets, which do not

Table 12. Comparison of properties of pellets with limestone plus bentonite and calcined lime.

\begin{tabular}{cccccccc}
\hline \multicolumn{1}{c}{ Pellets } & $\begin{array}{c}\text { Pellet's } \\
\text { Gr. Code }\end{array}$ & Basicity & $\begin{array}{c}\text { Induration } \\
\text { temperature, }{ }^{\circ} \mathrm{C}\end{array}$ & RI, \% & $\begin{array}{c}\text { RDI, \% of } \\
-3.15 \text { mm }\end{array}$ & $\begin{array}{c}\text { Swelling } \\
\text { Index, \% }\end{array}$ & $\begin{array}{c}\text { Apparent } \\
\text { porosity, \% }\end{array}$ \\
\hline Limestone plus bentonite added & A2-b & 0.25 & 1280 & 75.5 & 11.8 & 14.7 & 22.6 \\
Calcined lime added & B2 & 0.25 & 1280 & 74.7 & 12.1 & 14.9 & 23.54 \\
\hline
\end{tabular}

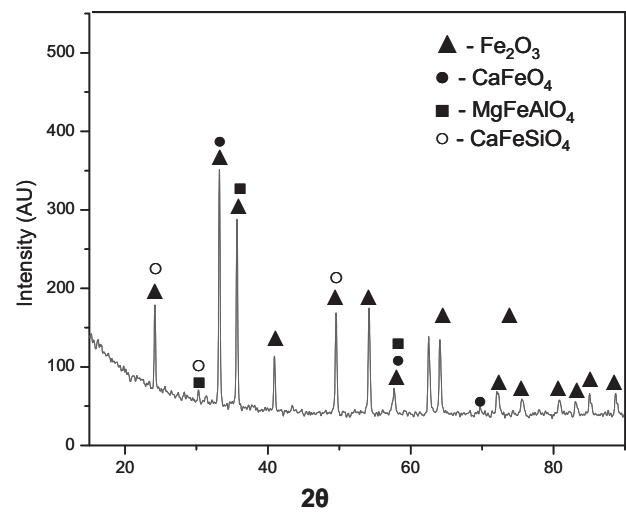

(a) Lime stone plus bentonite added pellet

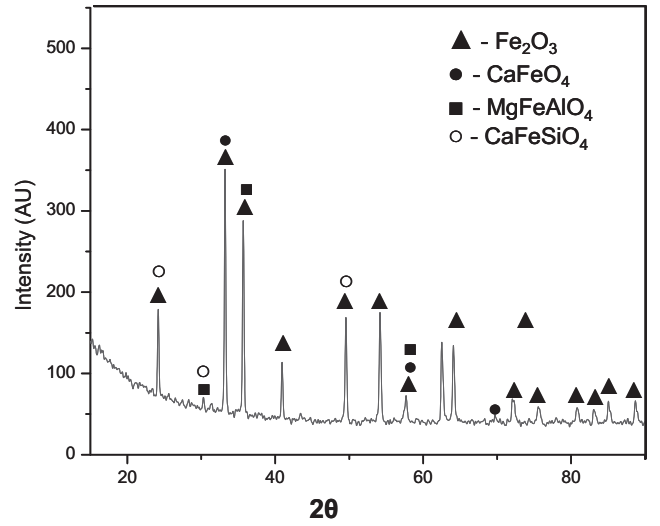

(b) Calcined lime added pellet

Fig. 15. X-ray diffraction patterns of limestone with bentonite added and calcined lime added pellets $(B=0.25)$.

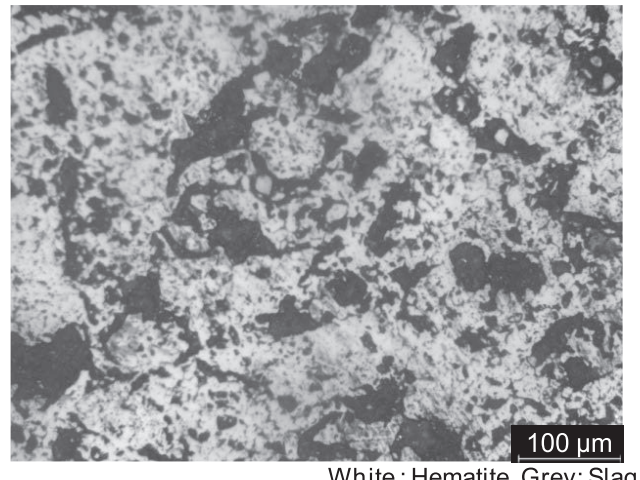

White: Hematite, Grey: Slag, Black: Pore

(a) Lime stone plus bentonite added pellet

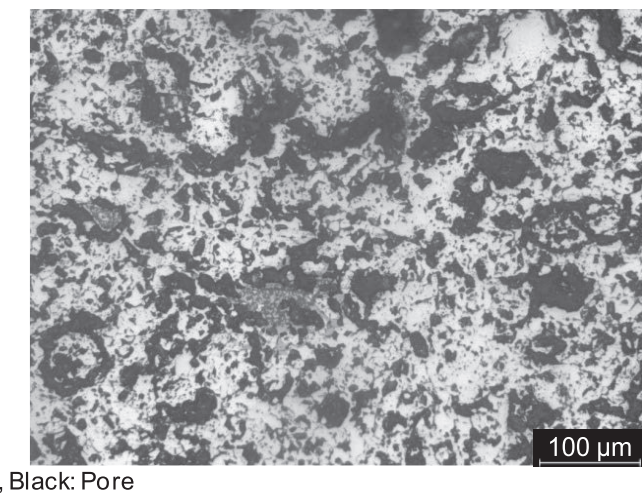

(b) Calcined lime added pellet

Fig. 16. Optical microstructure of limestone with bentonite added and calcined lime added pellets. 
appear any significant difference.

Thus, calcined lime can be used replacing lime stone and bentonite both. This in turn decreases the silica and alumina load to the pellets due to complete elimination of bentonite, which would be favorable for blast furnace operation also.

Since calcined lime ultimately transformed in to hydroxide lime during mix preparation for pellets, this study also reveals that lime either in form of hydroxide or calcined can be used for pellet making as a suitable binder that can replace both limestone and bentonite. However, due to powdery form and severe handling problem of hydroxide lime, calcined lime would be more suitable option. Instead of making hydroxide, calcined lime can be mixed with iron ore before ball mill for grinding followed by mixing in presence of water spray to make hydroxide and provide suitable quantity of free moisture (5-7\%). Thus, it is advisable to use calcined lime in pellet making that is available from the lime calcinations plant in almost in all integrated steel plant.

\section{Conclusions}

$\mathrm{MgO}$ in form of olivine reduces the RDI of high alumina hematite ore to a very low level and $0.6-1.0 \%$ requirement of it has been found to be optimum.

0.25 basicity in pellet with $1 \% \mathrm{MgO}$ and $1 \% \mathrm{C}$ shows lowest RDI and other properties of pellets viz. CCS, RI, swelling index and porosity are also very suitable at this level. Therefore, this composition/condition has been considered as optimum to study the effect of calcined lime in place of limestone and developed good quality calcined lime fluxed pellet from high alumina hematite ore fines, without using any bentonite and limestone.

Calcined lime fluxed pellet shows better strength properties of pellets in absence of carbon than lime stone plus bentonite added pellet. Addition of $1 \% \mathrm{C}$ in pellet improves CCS of limestone fluxed pellets as well as calcined lime pellets both. However, this strength improvement is much higher in limestone fluxed pellet and it reaches up to the level of calcined lime fluxed pellet in identical conditions. Only 10 min induration at $1280^{\circ} \mathrm{C}$ shows acceptable properties in both the pellets.

Calcined lime can be used as a good flux material in place of limestone which can provide better green pellets properties as well as desired strength at high temperature without using any bentonite. Thus, calcined lime can replace both limestone and bentonite in pellet. In turn it reduces alumina and silica load in pellet eliminating bentonite.

\section{Acknowledgement}

Authors thankfully acknowledge the management of Tata Steel Ltd, Jamshedpur, India for financially supporting this investigation. They express their sincere gratitude to the Director, CSIR-National Metallurgical Laboratory to accord permission in publishing the paper.

\section{REFERENCES}

1) A. Sharma and N. Rai: Proc. of 11th Int. Seminar on Mineral Processing Technology, MPT, Jamshedpur, (2010), 764.

2) M. Niesler, J. Stecko, L. Blacha and B. Oleksiak: Metalurgija, 53 (2014), 37.

3) T. C. Eisele and S. K. Kawatra: Miner. Proce. Extract. Metall. Rev., 24 (2003), 1.

4) R. P. de Souza: Proc. of 35th Annual Ironmaking Conf. Metallurgical Society of AIME Iron and Steel Division, Iron and steel society of AIME (ISS-AIME), New York, (1976), 182.

5) A. Sarkar, A. K. Mandal and O. P. Sinha: Int. J. Sci. Eng., 5 (2013), 9.

6) C. A. Holley: Proc. of 19th Biennial Conf. IBA, Institute for Briquetting and Agglomeration (IBA), Baltimore, Maryland, (1985), 165.

7) Anon: Pilot Plant Trial Report, 'Iron Ore with Lime Pelletizing Case Study', Clariant Mining, May, (2013), http://www.oms.clariant.com/ en-us/mining/Pages/Iron-Ore-with-Lime-Pelletizing-Case-Study-.aspx, (accessed 2014-4-3).

8) Y. M. Z. Ahmed and F. M. Mohamed: La Metallurgia Italiana, 1112 (2005), 31.

9) X.-h. Fan, M. Gan, T. Jiang, L.-S. Yuan and X.-1. Chen: J. Cent. South Univ. Tecchnol., 17 (2010), 732.

10) J. Pal, S. Ghorai, M. C. Goswami, S. Ghosh, D. Ghosh and D. Bandyopadhyay: ISIJ Int., 49 (2009), 210.

11) Y. M. Z. Ahmed and F. M. Mohamed: Eur. J. Miner. Process. Environ. Protect., 5 (2005), 17.

12) J. Pal, S. Ghorai, S. Agarwal, B. Nandi, T. Chakraborty, G. Das and S. Prakash: Miner. Process. Extr. Metall. Rev., in press, published online, DOI: $10.1080 / 08827508.2013 .873862$.

13) L. Bogdandy and H. J. Enngell: The Reduction of Iron Ore, 1st ed., Springer-Verlag, New York, (1971), 34.

14) L. Lu, R. J. Holmes and J. R. Manuel: ISIJ Int., 47 (2007), 349.

15) H. P. Pimenta and V. Seshadri: Ironmaking Steelmaking, 29 (2002), 175.

16) A. K. Das, A. Kumar, A. K. De and T. Mukherjee: Proc. of 60th Ironmaking Conf., ISS, Warrendle, PA, (2001), 973.

17) T. Umadevi, P. Kumar, F. L. Naveen, M. Prabhu, P. C. Mahapatra and M. Ranjan: ISIJ Int., 51 (2011), 14.

18) T. Umadevi, S. M. G. Kumar, S. Kumar, C. S. Gururaj Prasad and M. Ranjan: Ironmaking Steelmaking, 35 (2008), 327.

19) S. J. Ripke and S. K. Kawatra: Int. J. Miner. Process., 60 (2000), 181. 